www.jmscr.igmpublication.org

Impact Factor 5.244

Index Copernicus Value: 5.88

ISSN (e)-2347-176x ISSN (p) 2455-0450

crossref DOI:_http://dx.doi.org/10.18535/jmscr/v4i6.42

Journal Of Medical Science And Clinical Research

IGM Publication

An Official Publication of IGM Publication

\title{
To Compare two Different Doses of Tranexemic Acid in Congenital Cyanotic Heart Disease Patients Undergoing Open Heart Surgery
}

\author{
Authors \\ Sanjeeta Umbarkar, Swati Narnaware \\ Department of Anaesthesia, Seth G.S. Medical College \& K.E.M.Hospital, Mumbai \\ Corresponding Author \\ Sanjeeta Umbarkar \\ Email: Sanjeeta69@yahoo.com,9323273435
}

\begin{abstract}
Background: Blood conservation continues to be an important focus of interest in the field of cardiac surgery, given the increased awareness of blood-borne diseases and problems arising from multiple donor transfusions that are routine part of cardiac surgery. ${ }^{[1]}$ the search for methods and pharmacological agents to reduce blood loss after cardiac surgery is on-going. Use of antifibrinolytic has been studied and used in adult cardiac patients widely but there are not many studies regarding use of Tranexemic Acid in Cyanotic Congenital heart disease patients undergoing open heart surgery.

Methods: After ethic comitee permission 114 patients divided into two groups A and B.Group A -Injection Tranexemic Acid 10mg / $\mathrm{kg}$ IV followed by infusion of $1 \mathrm{mg} / \mathrm{kg}$ till end of surgery and Group B -three bolus doses of Injection Tranexemic Acid 10mg/kg IV,Blood loss, coagulation parametres,outcome of surgery studied with detail.
\end{abstract}

Result: It was found that three bolus doses of IV Tranexemic acid 10mg per $\mathrm{kg}$ is superior to IV bolus Followed by continuous infusion.

Keywords: Tranexemic acid, Congenital Cyanotic heart disease, Boluses, Blood loss.

\section{Introduction}

Blood conservation continues to be an important focus of interest in the field of cardiac surgery, given the increased awareness of blood-borne diseases and problems arising from multiple donor transfusions that are routine part of cardiac surgery. ${ }^{[1]}$ the search for methods and pharmacological agents to reduce blood loss after cardiac surgery is on-going. The use of antifibrinolytic agents such as tranexamic acid (TA) to reduce blood loss after paediatric cardiac surgery has been described in several studies ${ }^{[2,3]}$ these agents were found to be more effective in cyanotic rather than acyanotic patients and has been used to reduce postoperative blood loss in adult patients, but very few studies have been conducted in children. ${ }^{[4-6]}$ The dosage of TA has varied greatly in different reports. Reichert and colleagues ${ }^{[7]}$ used a single dose of $50 \mathrm{mg} / \mathrm{kg}$ after anaesthetic induction. Isetta ${ }^{[8]}$ et al used $15 \mathrm{mg} / \mathrm{kg}$ of TA before heparin and the same dose after protamine administration and compared the effects with those of low dose aprotinin. J.C.Horrow et al ${ }^{[9]}$ used a $10 \mathrm{mg} / \mathrm{kg}$ loading dose followed by an infusion of $1 \mathrm{mg} / \mathrm{kg} / \mathrm{hr}$. Vacharaksa et al ${ }^{[10]}$ used $15 \mathrm{mg} / \mathrm{kg}$ of TA after induction and repeated after protamine. In view of the large variation in the dosage of TA, we decided to compare the previously used regimens to assess their relative efficacy in children with cyanotic congenital heart disease undergoing corrective cardiac surgery. 


\section{Material and Methods}

The present clinical study is a randomized prospective single blinded study consisting of 114 children posted for corrective cardiac surgery for cyanotic heart disease. After the approval from institute's ethics committee and informed consent from the parents of the children, this study was conducted over a period of 2 years from May 2010 on 114 children in the age group ranging from 2 months to 15 years, undergoing corrective surgery for congenital cyanotic heart disease. Patients were selected from cardiovascular and thoracic surgery wards according to the inclusion and exclusion criteria as mentioned below

\section{Inclusion Criteria}

children aged between 2 yrs to 15 yrs with congenital cyanotic heart disease undergoing intracardiac corrective surgery on cardiopulmonary bypass (CPB)

\section{Exclusion Criteria}

Patients relative's refusal for the consent for study.

1. Patients with the history of allergy to the study drug.

2. Patients with renal dysfunction (serum creatinine more than $3 \mathrm{mg} / \mathrm{dl}$ )

3. Patients with a history of previous neurologic event like cerebral thrombosis, infarction or abcess.

4. Patients with congenital bleeding disorder

5. Patients with coagulation disorder

6. Emergency surgery

Patients were randomly assigned to group A and group B by asking the accompanying parent pick 1 of the 2 unmarked envelopes containing the group names. Group A received TA $10 \mathrm{mg} / \mathrm{kg}$ bolus dose after induction followed by an infusion of $1 \mathrm{mg} / \mathrm{kg} / \mathrm{hr}$. The infusion was continued till the end of surgery. Patients in group B received TA bolus dose of $10 \mathrm{mg} / \mathrm{kg}$ thrice i.e after anaesthetic induction, on $\mathrm{CPB}$ and after protamine reversal of heparin.

Anaesthetic management was standardized in all patients, who differed only in respect to the dose of TA given. All operations were performed by the same surgical team so that variation in the surgical technique as a cause of varying postoperative blood loss was ruled out. Preoperative Haemoglobin count, PCV and platelet count were recorded. Induction was done using midazolam $0.1 \mathrm{mg} / \mathrm{kg}$, fentanyl $10 \mathrm{ug} / \mathrm{kg}$ and rocuronium $1 \mathrm{mg} / \mathrm{kg}$ for muscle relaxation and maintained on air, oxygen and sevoflurane. Muscle relaxation was maintained with pancuronium $0.02 \mathrm{mg} / \mathrm{kg} / \mathrm{hr}$. After systemic heparinization with $300 \mathrm{U} / \mathrm{kg}$ of heparin, CPB was conducted on all patients using a membrane oxygenator and non occlusive roller pumps at moderate hypothermia $\left(28^{\circ} \mathrm{C}\right)$. The $\mathrm{CPB}$ circuit was primed with Ringer lactate solution $20 \mathrm{ml} / \mathrm{kg}$, sodium bicarbonate $7.5 \% 1 \mathrm{ml} / \mathrm{kg}$, mannitol $20 \%$, $0.5 \mathrm{gm} / \mathrm{kg}$ and heparin $100 \mathrm{U} / \mathrm{kg}$. Ultrafiltration was done on $\mathrm{CPB}$ to remove excess fluid.The CPB time was recorded as it indirectly affects the postoperative bleeding.Packed red blood cells were added if the haematocrit fell below $24 \%$ on $\mathrm{CPB}$.patients were weaned off $\mathrm{CPB}$ with the help of inotropic drugs like dopamine, dobutamine, noradrenaline milirinone, phenylephrine as per their respective doses. The time period from protamine administration to sternal closure was recorded in all patients and was used as an indirect index of the coagulation status, unless the delay in sternal closure was because of haemodynamic instability.( These patients were excluded from the study ). Activated clotting time (ACT) values were recorded on four occasions i.e. $5 \mathrm{~min}$ prior to heparin administration, $5 \mathrm{~min}$ after protamine administration, 1 hour postoperatively and 6 hour postoperatively. Postoperative care was taken by the surgical team blinded to the study groups who managed bleeding and blood products administration as per existing protocols. Packed red blood cells were transfused if the haematocrit fell below 33\%; fresh frozen plasma was transfused if haematocrit is above $33 \%$.Platelet concentrates were transfused in a dose range of 1 to 3 units per $10 \mathrm{~kg}$ body weight and cryoprecipitate was transfused in a dose of 2 units per $10 \mathrm{~kg}$ body weight if postoperative drain output were high Autotransfusion of shed mediastinal blood was not performed. Blood samples were collected after 6 hours postoperatively for coagulation studies that included bleeding time, clotting time prothrombin time and international normalized ratio. Postoperative cumulative blood loss from mediastinal and chest tube drains were recorded at 24 hours postoperatively.

\section{Results and Analysis}

This study consists of 114 patients who were randomized to two groups A and B.Group A received TA bolus at induction followed by 
infusion till the end of surgery.Group B received TA bolus thrice at induction,on CPB and after protamine reversal. To summarise normally distributed data, Mean \& SD is used and for not normally distributed data, Median and interquartile range is used. Appropriate statistical test like Chi square test (to compare proportions between two or groups) fisher's exact test are used.

The mean age in group A was $4.79 \pm 3.3$ years and in group B is $4.58 \pm 3.31$ years. The $p$ value is not statistically significant

Table1: Demographic data

\begin{tabular}{|l|l|l|l|}
\hline $\begin{array}{l}\text { No.of } \\
\text { patients }\end{array}$ & & $\begin{array}{l}\text { Group A(57) } \\
\text { (Bolus+Infusion) }\end{array}$ & $\underline{\underline{\text { GroupB(57) }}}$ \\
\hline$\underline{\text { Age }}$ & $\underline{\text { MeanSD }}$ & $4.79 \pm 3.30$ & $4.58 \pm 3.31$ \\
& $\underline{\text { Range }}$ & $\underline{2-15 \mathrm{yrs}}$ & $2-15 \mathrm{yrs}$ \\
\hline$\underline{\text { Gender }}$ & $\underline{\text { Male }}$ & $\underline{26}$ & $\underline{26}$ \\
& $\underline{\text { Female }}$ & $\underline{31}$ & $\underline{31}$ \\
\hline$\underline{\text { Weight }}$ & $\underline{\text { MeanSD }}$ & $9.92 \pm 4.87$ & $9.03 \pm 4.84$ \\
& $\underline{\text { Range }}$ & $9-25 \mathrm{~kg}$ & $9-22 \mathrm{~kg}$ \\
\hline
\end{tabular}

In our study demographic data (age, gender) was comparable in all groups.

The age of the cases were ranging from 2 years to 15 years with the mean for group A (bolus + infusion) was $4.79 \pm 3.30$ and mean for group B ( thrice bolus) was $4.58 \pm 3.31$ which is not statistically significant.(Table 1).

Out of 57 participants in group A 26 were male and 31 were female; in group B 26 males and 31 females. This was also statistically not significant. .(table2).

Thus the demographic data of two groups were not statistically significant that means all groups were comparable and randomised properly

Table 2- Percentage distribution of diagnosis among study groups

\begin{tabular}{|l|l|l|l|l|l|}
\hline $\begin{array}{l}\text { Diagnosi } \\
\mathrm{s}\end{array}$ & Surgery & $\begin{array}{l}\text { Total } \\
\text { Duratio } \\
\mathrm{n}(\mathrm{min})\end{array}$ & $\begin{array}{l}\text { Group } \\
\text { A }\end{array}$ & $\begin{array}{l}\text { Group } \\
\mathrm{B}\end{array}$ & Total \\
\hline CAVC & $\begin{array}{l}\text { CAVC } \\
\text { repair }\end{array}$ & 162 & $\begin{array}{l}2(3.50 \\
\%)\end{array}$ & $4(7 \%)$ & $\begin{array}{l}6(5.30 \% \\
)\end{array}$ \\
\hline $\begin{array}{l}\text { Tricuspid } \\
\text { atresia+V } \\
\text { SD }\end{array}$ & $\begin{array}{l}\text { Bilat.Gle } \\
\text { n shunt }\end{array}$ & 60 & $\begin{array}{l}2 \\
(3.50 \\
\%)\end{array}$ & $4(7 \%)$ & $\begin{array}{l}6(\% .30 \\
\%)\end{array}$ \\
\hline TAPVC & $\begin{array}{l}\text { Correcti } \\
\text { on }\end{array}$ & 130 & $4(7 \%)$ & $5(8.8 \%$ & $\begin{array}{l}9(7.90 \% \\
)\end{array}$ \\
\hline TGA & $\begin{array}{l}\text { Arterial } \\
\text { Switch }\end{array}$ & 240 & $\begin{array}{l}7 \\
(12.30\end{array}$ & $\begin{array}{l}5 \\
(8.80 \%\end{array}$ & $\begin{array}{l}12(10.50 \\
\%)\end{array}$ \\
\hline TOF & $\begin{array}{l}\text { Intracard } \\
\text { iac } \\
\text { repair }\end{array}$ & & $\begin{array}{l}42(73 . \\
70 \%)\end{array}$ & $\begin{array}{l}39(68.4 \\
\%)\end{array}$ & $\begin{array}{l}81(71.1 \\
\%)\end{array}$ \\
\hline
\end{tabular}

As shown in table 2 diagnosis and surgery are not the confounding factors in the study.

As shown in table 6,preop $\mathrm{Hb} \mathrm{PCV}$ and platelet count is same in both the study groups.
Graph 1:

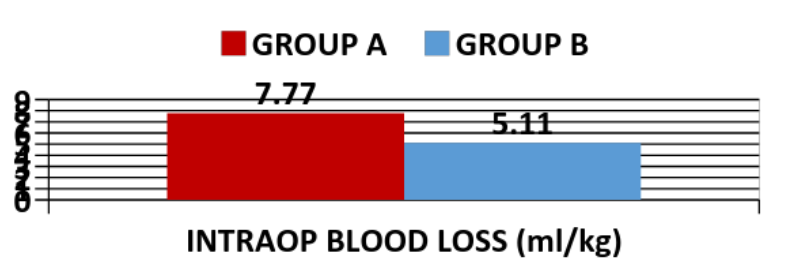

As shown in Graph 1, intraoperative blood loss in group A was $7.77 \pm 1.95$ and in group B was 5.11 1.73. $p$ value was significant. Thus the intraoperative blood loss was significantly less in group B as compared to group A.

RBC transfused intraoperatively was $4.79 \pm 1.42$ $\mathrm{ml} / \mathrm{kg}$ in group A and in group B it was $3.31 \pm$ $2.31 \mathrm{ml} / \mathrm{kg}$. FFP transfused intraoperatively was $3.19 \pm 1.49 \mathrm{ml} / \mathrm{kg}$ in group A and in group B it was $2.12 \pm 1.64 \mathrm{ml} / \mathrm{kg}$. $\mathrm{p}$ value was significant for both RBC and FFP.thus the requirement for intraoperative $\mathrm{RBC}$ and FFP transfusion was significantly less in group B as compared to group A.

Platelets transfused intraoperatively was $1.00 \pm$ $0.85 \mathrm{ml} / \mathrm{kg}$ in group A and in group B it was 0.94 $\pm 0.78 \mathrm{ml} / \mathrm{kg}$.p value was not significant. Hence the platelet requirement intaoperatively was same in both the groups.

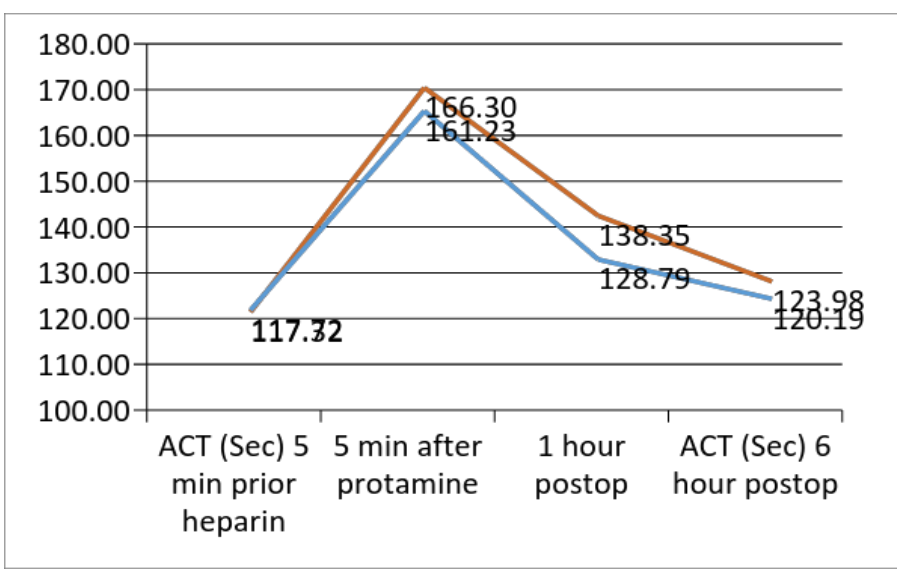

ACT values recorded $5 \mathrm{~min}$ prior to heparin administration and after protamine administration was same in both the groups. but the ACT recorded 1 hour and 6 hours postoperatively was significantly less in group B as compared to group 


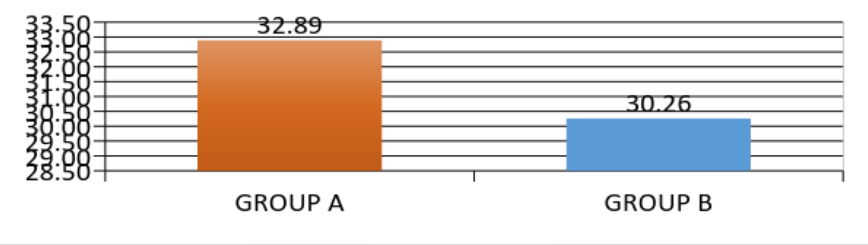

The mean sternal closure time(min) in group A was $32.89 \pm 7.25$ and in group B was $30.26 \pm 6.58$ which is statistically significant. As shown in table 12, the mean CPB time in group A was 2.66 \pm 1.58 and in group B it was $2.94 \pm 1.49$. $P$ value is not significant thus CPB time is same in both the study groups.

Bleeding time in group A is $144.75 \pm 19.21$ and in group B it was $105.37 \pm 7.9$. The clotting time in group A was $368.88 \pm 50.9$ and in group B 260.74 \pm 30.3 . The $P$ value is significant for both $\mathrm{BT}$ and $\mathrm{CT}$ thus the mean BT and CT values are significantly less in group B as compared to group A.

Mean PT in group A was $17.02 \pm 1.97$ and in group B $14.04 \pm 1.24$. The INR value in group A was $1.34 \pm 0.19$ and in group B was $1.13 \pm 0.22$. The $P$ value was significant for both PT and INR thus the mean PT and INR values are significantly less in group B as compared to group A.

The mean $\mathrm{Hb}$ in group $\mathrm{A}$ recorded at 24 hours post operatively was $12.25 \pm 1.11$ and in group $\mathrm{B}$, $12.89 \pm 1.07$. The mean PCV for group A was $37.7 \pm 4.13$ and in group $\mathrm{B}$ was $39.21 \pm 3.52$. $\mathrm{P}$ value was significant for both $\mathrm{Hb}$ and $\mathrm{PCV}$ recorded 24 hours post operatively thus the $\mathrm{Hb}$ and PCV values were significantly high in group $\mathrm{B}$ as compared to group A.

Mean platelet count in group A was $2.11 \pm 0.6$ and in group B $2.03 \pm 0.59$ recorded 24 hours post operatively. The $\mathrm{P}$ value was not significant, thus the platelet count was same in both the study groups.

The mean drain output in group A was $11.67 \pm$ 6.03 and in group B it was $7.0 \pm 5.34$ which is statistically significant. The drain output was significantly less in group B as compared to group A

Mean $\mathrm{RBC}(\mathrm{ml} / \mathrm{kg})$ transfused postoperatively in group A was $4.56 \pm 8.47$ and in group B it was $1.75 \pm 5.71$ which is statistically significant. The mean FFP transfused $(\mathrm{ml} / \mathrm{kg}$ ) postoperatively in group A $18.86 \pm 2.68$ and in group B is $11.23 \pm$ 3.57 which is statistically significant.
Platelet transfused in 24 hours post operatively was $1.28 \pm 0.96$ for group A and $1.21 \pm 0.77$ for group B. $\mathrm{P}$ value is not significant. Platelet requirement in post operative period was same for both groups.

\section{Discussion}

Children undergoing cardiac surgery with $\mathrm{CPB}$ have a higher rate of postoperative bleeding than that seen in adult patients. ${ }^{[49]}$ This is due to several factors.

There is disproportionate exposure to the nonendothelialized extracorporeal circuit, which produces an inflammatory-type response. This inflammatory response to $\mathrm{CPB}$ is inversely related to patient age; the younger the patient, the more pronounced the response. ${ }^{[50]}$ Because complement and platelet activation are linked to the activation of other protein systems in the blood (i.e., fibrinolytic), it is probable that this haemostatic activation, which results in impaired haemostasis and increased bleeding tendency, plays a major role during paediatric cardiac surgery.

The type of surgery performed in children usually involves more extensive reconstruction and suture lines, creating more opportunities for surgical bleeding than in adult cardiac patients. Congenital cardiac anomalies like TGA, CAVC and tricuspid atresia require corrective surgeries of longer duration as compared to other other cardiac anomalies like valular repair, PDA ligation and VSD repair. Thus the CPB time is also prolonged owing to longer duration of surgery. Prolonged CPB time will aggravate the inflammatory and haemostatic effects of $\mathrm{CPB}$, thus increasing the tendency of intraoperative and postoperative bleeding.

The immature coagulation system in children also contributes to impaired haemostasis. ${ }^{[51]}$ The procoagulant and factor levels are reduced in young patients with congenital heart disease due to immature or impaired hepatosynthesis. ${ }^{[52]}$

Also, children with congenital cyanotic heart disease have decreased platelet aggregability owing to hypoxia and polycythemia ${ }^{[53]}$. Hence the need for platelet transfusion is more in these patients during and after surgery.

The haemostatic effects of CPB are myriad. Exposure of blood to the surfaces of the bypass circuitry is a profound stimulus for inflammatory upregulation, and activation of the haemostatic 
system is a component of the normal inflammatory response.

$\mathrm{CPB}$ is thought to activate the intrinsic and extrinsic haemostatic pathways and to directly affect platelet functionality. Current concepts in vascular biology and haemostasis implicate tissue factor-bearing leukocytes and endothelial cells activated by the inflammatory stimulus of bypass and circulating tissue thromboplastin generated from the surgical field. ${ }^{[54][55][56]}$ Activation of the intrinsic pathway can occur by activation of factor XII to factor XIIa on the various surfaces of the bypass circuit. ${ }^{[54]}{ }^{[57]}$ Generation of thrombin by the tissue factor pathway assumes a primary role in CPB-associated haemostatic disorder can complicate haemostasis after CPB is terminated and heparin is reversed by protamine.

In addition to activating the extrinsic and intrinsic haemostatic pathways, CPB directly affects platelet function through the effects of haemodilution, hypothermia, and contact activation by bypass circuit materials. Platelets express numerous glycoproteins on their surface that serve as receptors for several circulating ligands, such as fibrinogen, thrombin, and collagen ${ }^{[54]}$ The components of the bypass circuit adsorb circulating proteins that can serve as foci for platelet attraction and adherence. These surface-bound platelets activate and release the contents of their cytoplasmic granules, which can then serve as localized sources of thrombin generation or embolize to initiate microvascular thrombosis. ${ }^{[59]}$ The resulting functional platelet disorder can complicate haemostasis after CPB is terminated and heparin is reversed by protamine.

Fibrinolytic activity is also increased by CPB. Contact activation of factor XII, prekallikrein, and high-molecular-weight kininogen leads to fibrinolytic activation through activation of endothelial cells to produce tissue plasminogen activator (t-PA) and lysis of fibrin strands and the fibrin precursor fibrinogen. ${ }^{[54]}$ [60] Endothelial cells themselves are vulnerable to inflammatory activation by the effects of CPB. Vascular endothelium is an active substrate that expresses and releases anticoagulant and procoagulant factors. ${ }^{[55]}$ Endothelial cells, when exposed to hypoxia or inflammatory mediators during bypass, can induce a relatively prothrombotic state that leads to upregulation of tissue factor, accelerated platelet adhesion, and increased expression of leukocyte adhesion molecules ${ }^{[54] 55]}$
Platelet dysfunction and fibrinolysis are important causes of increased blood loss during and after cardiac surgery performed under CPB. ${ }^{[6]}$ As children with congenital cyanotic heart disease have a deranged coagulation system, with preexisting altered platelet function and enhanced fibrinolysis, they are more prone to excessive postoperative blood loss because these preexisting defects are worsened by CPB. ${ }^{[10]}$

Patients with congenital cyanotic heart disease are therefore known to benefit from antifibrinolytics such as tranexamic acid which has been used in several studies to reduce intraoperative and postoperative blood loss ${ }^{[3],[8]}$. Tranexamic acid is an antifibrinolytic agent, 10 times more potent than epsilon aminocaproic acid with more effective binding to plasminogen.

However there is no agreement on the optimal dosage of TA or the timing of administration specially in patients with congenital cyanotic heart disease. Reichert and colleagues studied TA in 88 children given a single dose of $50 \mathrm{mg} / \mathrm{kg}$ and found no benefit in 64 non cyanotic patients in terms of reduced bleeding or transfusion requirements. Isetta ${ }^{[8]}$ et al used $15 \mathrm{mg} / \mathrm{kg}$ of TA before heparin and the same dose after protamine administration and compared the effects with those of low dose aprotinin in cardiac surgery. He found both TA and aprotinin to be equally effective in reducing blood loss in cardiac surgery. J.C.Horrow et al ${ }^{[9]}$ used a $10 \mathrm{mg} / \mathrm{kg}$ loading dose of TA followed by an infusion of $1 \mathrm{mg} / \mathrm{kg} / \mathrm{hr}$ and compared it with desmopressin in cardiac surgery and observed that TA significantly reduced the postoperative blood loss and transfusion requirements in cardiac surgical patients. Vacharaksa et al ${ }^{[10]}$ compared single dose versus double administration TA $15 \mathrm{mg} / \mathrm{kg}$ children with cyanotic CHD undergoing open heart surgery. He observed no significant difference in postoperative blood loss or blood and blood product requirement between those who received a single dose of TA compared with those who received two doses.

This present study shows that the thrice bolus dose of TA is more efficacious in reducing postoperative blood loss and blood products requirements as compared to the bolus with infusion dose. the above data shows that the thrice bolus dose has better effect on the coagulation status than the bolus and infusion dose. The mean preop $\mathrm{Hb}, \mathrm{PCV}$ and platelet count in group $\mathrm{A}$ and Group B is not statistically significant. But the 
mean post operative $\mathrm{Hb}$ (gm\%) in group A 12.25 \pm 1.11 and in group B was $12.89 \pm 1.07$ which is statistically significant.The mean PCV (\%)in group A was37.7 \pm 4.13 and in group B was 39.21 \pm 3.52 which is statistically significant . the mean postoperative platelet count(lac/cumm) in group A was $2.11 \pm 0.6$ and group B was2.03 \pm 0.59 which is not significant. This shows that the thrice bolus dose of TA is more effective in controlling blood loss intraoperatively and postoperatively and improving the coagulation status in patients undergoing corrective cardiac surgery for cyanotic heart disease.. But platelet count is not affected by the different dose of Tranexemic acid.

In view of the large variation in the dosage of TA, we decided to compare the previously used regimens to assess their relative efficacy in children with cyanotic congenital heart disease undergoing corrective cardiac surgery. This is a randomized prospective study comparing the efficacy of two different doses of TA. Here we randomly divided the patients in two groups; group A received TA bolus $10 \mathrm{mg} / \mathrm{kg}$ at induction followed by infusion at the rate of $1 \mathrm{mg} / \mathrm{kg} / \mathrm{hr}$ continued till the end of surgery.

\section{Conclusion}

Though use of Tranexemic acid is very popular in open heart cardiac surgeries the desired effects may not achieved in various regime used. The therapeutic levels of Tranexemic acid are maintained throughout the surgery both during $\mathrm{CPB}$ and off $\mathrm{CPB}$ thus combating the undesirable effects on $\mathrm{CPB}$ in three bolus doses regime whereas the infusion dose was insufficient to cause sustained antifibrinolysis on CPB in Bolus followed by Infusion regime group. Hence it is safer and useful regime in open heart surgical cyanotic heart disease paediatric patients, . Limitation of study is Thromboelastography (TEG) should have been used as a guide to assess the cause of bleeding and for administration of blood components, but due to its lack of availability, it was not used in our study.

\section{References}

1. Janssens $M$ : Hartstein $G$ Treatment of excessive mediastinal bleeding after cardiopulmonary bypass. Ann Thoracic Surg 62 : 1951-1954, 1996

2. Karski JM, Teasdale SJ, Norman PH, et al : Prevention of postbypass bleeding with tranexamic acid. J Cardiothoracic Vasc Anaesth 7:431-435, 1993

3. Horrow JC, Van riper DF, Strong MD et $a l$ :The dose response relationship of tranexamic acid. Anaesthesiology 1995;82:383-92

4. Verstraete $M$. Clinical application of inhibitors of fibrinolysis. Drugs 1985;29:236 -61

5. Horrow JC Hlavacek MD, strong D, et al: prophylactic tranexamic acid decreases bleeding after cardiac operations. J Thorac Cardiovasc Surg 1990; 99: 70-4

6. Jansenns M,Hartstein G,David JL :reductions in the requirements for allogenic blood products:pharmacologic methods.Ann Thoracic Surg1996;62:194450

7. Reichert $C$, Zonis $Z$ Seear $M$, et al: The effect of preoperative tranexamic acid on blood loss after cardiac operations in children. J Thorac Cardiovasc Surg 111 : 982-987,1996

8. Isseta C, Samat $C$, Kotaiche $M$. low dose aprotinin or tranexamic acid treatment in cardiac surgery. Anaesthesiology 1991;75:80A

9. Horrow JC, Van Riper DF, Strong D, et al :Haemostatic effects of desmopressin and tranexamic acid during cardiac surgery. Circulation 1991;84:2063-70

10. Vacharaksa $K$ : Tranexamic acid for reducing the need for blood and blood component therapy in children undergoing surgery for congenital cyanotic heart disease, J Med Assoc Thai. 2002 Sep;85 Suppl 3:S904-9

11. Dubber AH, Mc nicol GP, Douglas as. amino methyl cyclohexane carboxylic acid (amcha), a new synthetic fibrinolytic inhibitor. br j haematol. 1965 mar;11:237245. [pubmed]

12. Nilsson I M, Andersson L Bjorkmann S.E.(1965),Acta Medica Scandinavia Supplemen. No.448

13. Gibbs JR, Corkill AG. Use of an antifibrinolytic agent (tranexamic acid) in the management of ruptured intracranial aneurysms. Postgrad Med J. 1971 Apr;47(546):199-200.PubMed

14. Reid RW,Zimmerman AA,Laussen $P C$, Mayer JE,Gorlin JB,Burrows FA.The 
efficacy of tranexamic acid versus placebo in decreaseing blood loss in pediatric patients undergoing repeat cardiac surgery.Anesth Analg 1997;84:990-6

15. Dunn CJ, Goa : tranexamic acid a review of its use in surgery and other indications/.www.ncbi.nlm.nih.gov/pubme $\mathrm{d} / 10400410$

16. Chauhan $S$ et al, Dose comparison of tranexamic acid in pediatric cardiac surgery, Indian J Med Res. 2003 Aug;118:86-9., Department of cardiac anaesthesia,Cardiothoracic Center, All India Institute of Medical Sciences, New Delhi, India

17. Giordano et al Ann Thorac Surg. 2012 Oct;94(4):1302-6. doi: 10.1016/j. athoracsur.2012.04.078. Epub 2012 Jul 21.

18. Sagripanti A, Carpi A: Antithrombotic and prothrombotic activities of the vascular endothelium. Biomed Pharmacother 2000; 54:107-111.

19. 19 .Freedman JE, Loscalzo J: Nitric oxide and its relationship to thrombotic disorders. J Thromb Haemost 2003; 1:1183-1188.

20. Kato $H$ : Regulation of functions of vascular wall cells by tissue factor pathway inhibitor: Basic and clinical aspects. Arterioscler Thromb Vasc Biol 2002; 22:539-548.

21. May AE, Neumann FJ, Preissner KT: The relevance of blood cell-vessel wall adhesive interactions for vascular thrombotic disease. Thromb Haemost 1999; 82:962-970.

22. $W u \quad K K$ Thiagarajan $P$ : Role of endothelium in thrombosis and hemostasis. Annu Rev Med 1996; 47:315-331.

23. Grignani G, Maiolo A: Cytokines and hemostasis. Haematologica 2000; 85:967-972.

24. Westrick RJ, Eitzman DT: Plasminogen activator inhibitor-1 in vascular thrombosis. Curr Drug Targets 2007; 8:966-1002.

25. Parolari A, Mussoni L, Frigerio M, et al: Increased prothrombotic state lasting as long as one month after on-pump and offpump coronary surgery. $\mathbf{J}$ Thorac Cardiovasc Surg 2005; 130:303-308.
26. Kassis J, Hirsh J, Podor TJ: Evidence that postoperative fibrinolytic shutdown is mediated by plasma factors that stimulate endothelial cell type Iplasminogen activator inhibitor biosynthesis. Blood 1992; 80:1758-1764.

27. Hartwig JH: The platelet: form and function. Semin Hematol 2006; 43:S94100.

28. Andrews RK, Berndt $\quad M C$ : Platelet physiology and thrombosis. Thromb Res 2004; 114:447-

29. Chen J, Lopez JA: Interactions of platelets with subendothelium and endothelium. Microcirculation 2005; 12:235-246.

30. Chaer RA, Graham JA, Mureebe L: Platelet function and pharmacologic inhibition. Vasc Endovascular Surg 2006; 40:261-267.[30]

31. Furie B, Furie BC: Thrombus formation in vivo. J Clin Invest 2005; 115:3355-3362.

32. Fullard JF: The role of the platelet glycoprotein IIb/IIIa in thrombosis and haemostasis. Curr Pharm Des 2004; 10:1567-1576.

33. Hoffman $M$ : Remodeling the blood coagulation cascade. J Thromb Thrombolysis 2003; 16:17-20.

34. Coughlin SR: Protease-activated receptors in hemostasis, thrombosis and vascular biology. J Thromb Haemost 2005; 3:1800-1814.

35. Schenone $M$, Furie BC, Furie B: The blood coagulation cascade. Curr Opin Hematol 2004; 11:272-277.

36. Mann KG, Brummel-Ziedins K, Orfeo T, Butenas S: Models of blood coagulation. Blood Cells Mol Dis 2006; 36:108-117.

37. Gomez K, McVey JH: Tissue factor initiated blood coagulation. Front Biosci 2006; 11:1349-1359.

38. KE, Osterud B: Eilertsen Tissue factor: (patho)physiology and cellular biology. Blood Coagul Fibrinolysis 2004; 15:521538.

39. Gailani D, Renne T: The intrinsic pathway of coagulation: A target for treating thromboembolic disease?. J Thromb Haemost 2007; 5:1106-1112.

40. Hoffman M: A cell-based model of coagulation and the role of factor VIIa. Blood Rev 2003; 17(Suppl 1):S1-S5.[40] 
41. Esmon CT: Crosstalk between inflammation and thrombosis. Maturitas 2004; 47:305-314.

42. Furie $B$, Furie $B C$ : In vivo thrombus formation. J Thromb Haemost 2007; 5(Suppl 1):12-17.

43. Mosesson $M W$ : Fibrinogen and fibrin structure and functions. $\mathrm{J}$ Thromb Haemost 2005; 3:1894-1904.

44. Crawley JT, Zanardelli S, Chion CK, Lane $D A$ : The central role of thrombin in hemostasis. J Thromb Haemost 2007; 5(Suppl 1):95-101.

45. Barshtein G, Ben-Ami R, Yedgar S: Role of red blood cell flow behavior in hemodynamics and hemostasis. Expert Rev Cardiovasc Ther 2007; 5:743-752.

46. Medcalf RL: Fibrinolysis, inflammation, and regulation of the plasminogen activating system. J Thromb Haemost 2007; 5(Suppl 1):132-142.

47. Cesarman-Maus G, Hajjar KA: Molecular mechanisms of fibrinolysis. $\mathrm{Br} \mathrm{J}$ Haematol 2005; 129:307-321

48. Despotis GJ, Joist JH, Goodnough LT: Monitoring of hemostasis in cardiac surgical patients: impact of point-of-care testing on blood loss and transfusion outcomes. Clin Chem 1997; 43:16841696

49. Manno CS, Hedberg KW, Kim HC, et al: Comparison of the hemostatic effects of fresh whole blood, stored whole blood, and components after open heart surgery in children. Blood 1991; 77:930.

50. Greeley WJ, Bushman GA, Kong DL, et al: Effects of cardiopulmonary bypass on eicosanoid metabolism during pediatric cardiovascular surgery. $J$ Thorac Cardiovasc Surg 1988; 95:842

51. 51.. Andrew M, Paes B, Milner R, et al: Development of the human coagulation system in the full-term infant. Blood 1987; 70:165.

52.52.. Colon-Otero G, Gilchrist GS, Holcomb GR, et al: Preoperative evaluation of hemostasis in patients with heart disease. Mayo Clin Proc 1987; 62:379.

53. J. Anthony Ware, William H. Reaves, Janet K. Horak and R. Thomas : Ann Thorac Surg 1983;36:289-294
54. Kottke-Marchant $K, \quad$ Sapatnekar $S$ : Hemostatic abnormalities in cardiopulmonary bypass: Pathophysiologic and transfusion considerations. Semin Cardiothorac Vasc Anesth 2001; 5:187206.

55. Boyle Jr EM, Verrier ED, Spiess BD: Endothelial cell injury in cardiovascular surgery: The procoagulant response. Ann Thorac Surg 1996; 62:1549-1557.

56. Boisclair MD, Lane DA, Philippou $\mathrm{H}$, et al: Mechanisms of thrombin generation during surgery and cardiopulmonary bypass. Blood 1993; 82:3350-3357.

57. Burman JF, Chung HI, Lane DA, et al: Role of factor XII in thrombin generation and fibrinolysis during cardiopulmonary bypass. Lancet 1994; 344:1192-1193.

58. Edmunds Jr LH, Colman RW: Thrombin during cardiopulmonary bypass. Ann Thorac Surg 2006; 82:2315-2322.

59. Edmunds Jr LH: Inflammatory response to cardiopulmonary bypass. Ann Thorac Surg 1998; 66:S12-S16.

60. Collen D: The plasminogen (fibrinolytic) system. Thromb Haemost 1999; 82:259- 